\title{
Milliequivalent per Microgram
}

National Cancer Institute

\section{Source}

National Cancer Institute. Milliequivalent per Microgram. NCI Thesaurus. Code C70581.

A unit of relative amount of substance content equivalent to the content at which one

millionth of a gram of mixture contains one thousandth of an equivalent of a component.

The unit is also used as a dose calculation unit. 